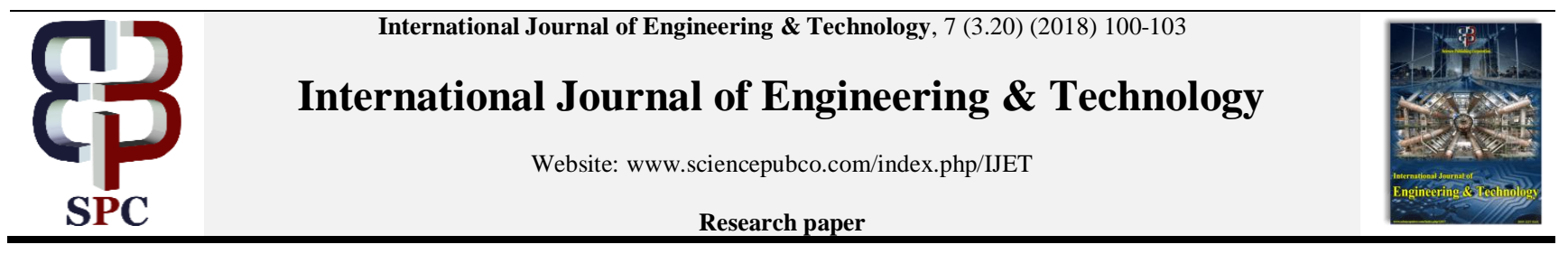

\title{
Factors Affecting Talent Management towards Gen Y
}

\author{
${ }^{1}$ Fadillah Ismail, ${ }^{2}$ Ainul Mardhiyah Nor Aziz, ${ }^{3}$ Irmawati Norazman, ${ }^{4}$ Siti Anisah Atab@Yaakub \\ ${ }^{1,4}$ Faculty of Technology Management and Business, Universiti Tun Hussein Onn Malaysia, \\ ${ }^{2,3}$ Faculty of Management, Universiti Teknologi Malaysia, 81310 Skudai, Johor, Malaysia \\ 86400 Batu Pahat, Malaysia \\ *Corresponding Author Email: fadillah@uthm.edu.my
}

\begin{abstract}
Talent management within organization is a human resource strategy that seeks to develop and retain talented and potential employee. Talent management among Gen Y has obtained critical enthusiasm for the organization. The research objective for this study is to develop conceptual framework of factors affecting talent management among Gen Y in organizations. Gen Y was chosen as the concentration of this investigation in relationship between factors affecting talent management (globalization, knowledge economy, changing the world work, demographic changes, and technology) and talent management. This study enhances to the new challenges and fulfill critical gap that now exists in organization. Thus, this research is important to academia and manager's level to develop talent management and human resource strategy in the organizations.
\end{abstract}

\section{Keywords: Human Resource, Talent Management, Gen Y, Management}

\section{Introduction}

There are many ways to deal with dealing with the most significant resources of an organization, including human resource management [10], human capital management [36] and other. Notwithstanding, over the most recent 20 years' huge consideration has pulled in exploiting skills of organizations' best representatives marked as stars, precious stones, and most regularly gifts ([20]; [35]). Organizations can barely contend without exceptionally talented specialists and without the ceaseless interest in the human capital. To have the ideal individuals in the correct spots and in the opportune time is basic for any association to accomplish the competitive advantage. Besides, the accomplishment of any association depends unequivocally on having skilled people. Hence, the capacity to manage ability and ability administration (TM) viably has been and will be one of the greatest difficulties confronting associations today. A current report led in the given range ([7], [12]) found that the talent management is getting

to be noticeably one of the principle apparatuses of business intensity.

Amid the most recent 20 years' talent management, has developed from an inadequately organized wonder to the hypothetical origination that is generally known and broadly portrayed in the writing [16]. In spite of the fact that there are diverse premises of talent management as a field of study, its concentration remains for the most part unaltered. Talent management underscores exceptional projects made with the end goal of representatives' potential advancement [3]. While portraying talent management specialists [23] as some processual angles identified with the improvement of extraordinary workers (gifts) [30]. While contemplations on ability administration concentrate mostly on its processual nature, to date moderately little consideration, has been paid to think about its authoritative level possibilities [16].

\section{Literature Review}

According to many authors ([22]; [36]; [8] the main factors affecting talent management are as follows:

\subsection{Globalization}

Globalization gives associations and managers new open doors, makes the world more various and more coordinated, rivalry is more extraordinary, multifaceted and to a great degree far reaching. Worldwide mindfulness consolidates pondering interdependencies that exist all through the world and the feeling of living in a worldwide group as opposed to a nation particular one ([38]; [20]). The pool of capable people has been developing and is relied upon to keep on growing sooner rather than later, predominantly as a result of expanded instructive open doors in rising countries. Furthermore, the interest for such ability is probably going to become much quicker in a similar period. In light of information from 22 nations and 12 businesses, a World Economic Forum think about anticipated that tremendous ability holes between the free market activity of exceptionally talented specialists would show up by 2020 (World Economic Forum, 2011). 


\subsection{The Knowledge Economy}

Learning is utilized as the most imperative wellspring of the organization's competitive advantage; the alleged information laborers are ending up deliberately critical for associations; [11] distinguished a learning specialist as "somebody with high degrees of aptitude, training or encounter and the main role of their employment includes the creation, dissemination, or utilization of information" [28] recommended that the learning specialists complete their work in a procedure situated condition. Information laborers are utilized in firms to play out a capacity and to contribute their offer in the creation of merchandise and administration. In the process-situated condition, useful learning stock (usage of information stock) is considered as the stream of information, and learning specialists are to a lesser extent a stock than stream.

\subsection{Changing the World of Work}

Changing the universe of work portrayed by making new types of work and new occupations, by the disparity between the required and accessible aptitudes, by the lack of high-talented laborers, by the ascent in the worldwide and virtual workforce. Today, work life is described by multifaceted nature, eccentrics, and frailty). Gen Y holds an unexpected outlook in comparison to their antecedents which adds to their associations by discovering deficiencies with plans of action and techniques, and proposing innovation driven substitutes for more proficient efficiency [15]. They are mindful and can recognize what items will showcase best to their own era. They are socially cognizant and are focused on offering back to their groups also [15]. They likewise have confidence in the rehash of conventional procedures. Millennial specialists are exceptionally versatile and open to change, with a high bounce back rate. For instance, in the event that they have fizzled at making a deal, they can ricochet back rapidly [15].

\subsection{Demographic Changes}

Statistic changes are gathering in the age profile of the workforce (maturing workforce versus Gen $\mathrm{Y}$ and more youthful eras) and in the structure of the workforce (expanding decent variety, distinctive ranges of abilities, shifted desire). The Gen Y be hopeful [27], and be versatile to change [26]. Besides, they look for adaptability [31], are autonomous, want a healthier lifestyle [9]. Adaptability is vital for all people, particularly Generation Y who esteem time-off as for their own life. Management can utilize adaptable work hours and reward pay as inspiration, in light of the fact that these prizes altogether impact their individual execution. Basically, chiefs should endeavor to "reexamine and retool enrollment, maintenance, and advancement systems regarding the combination of different eras into the workforce condition" [13].

\subsection{Technology}

Innovation makes the world quicker and more associated, significantly affects working environments and the workforce. This era has been formed by parental abundances, PCs [33], and sensational mechanical advances. A standout amongst the most regularly announced attributes of this era is their solace with innovation [27].

\subsection{Gen Y}

Gen Y are moving on from school and entering the work pool as a huge and compelling gathering. As the most seasoned era of representatives (Baby Boomers) are resigning, most of the workforce is Generation $\mathrm{X}$ people; numerous supervisors are seeing the need to draw in and hold this new Gen Y pool of gifted specialists [32]. The workforce has been changing from a customary chain of command mentality, to a more different and broad arrangement of free, competent people. "A more noteworthy comprehension of the wants, prerequisites, and business-related estimations of the most up to date era of people may give a win-win opportunity where both the businesses and workers advantage" [37].

\subsection{Talent Management}

Talent management systems for Generation $\mathrm{Y}$ are gotten from Strategic Human Resources Management (SHRM) programs that coordinate choices about individuals with the outcomes the association expects to accomplish ([1]; [2]). SHRM amalgamates Human Resource Management (HRM) into the association arranging process and accentuates on human asset exercises that help the mission, objectives, and building solid human asset administration connections. It is kept up that Human Resource Management hones increment representatives' ability and impulse to work which thusly impacts on authoritative execution.

\section{Conceptual Framework}

Based on Figure 1, factors affecting talent management as independent variable and talent management and talent management as dependent variable. Also, Gen Y as mediating role between the relationship. The illustration of the theoretical framework:

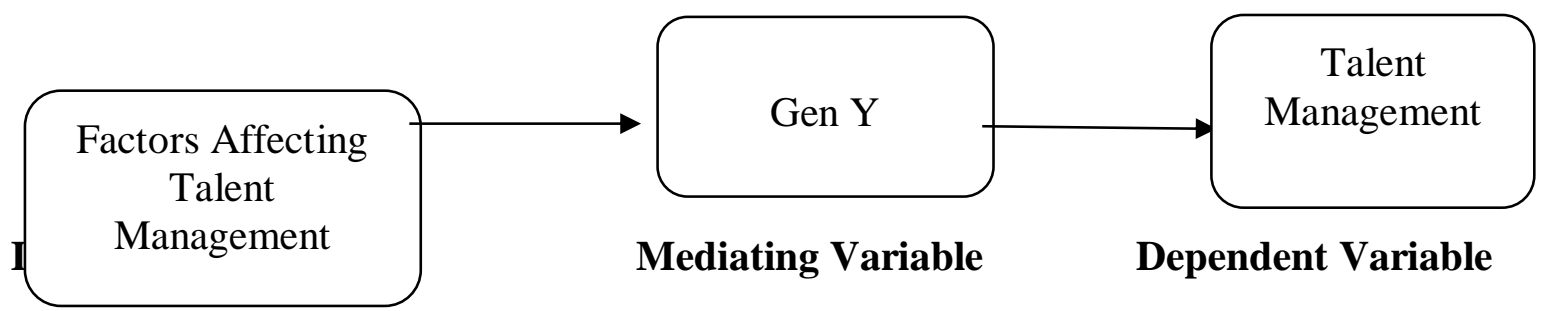

Figure 1: Theoretical Framework

Adapted from [22]; [36]; [8] 


\section{Suggestion and Discussions}

In this way, it is the part of HRD to create and accommodate these high-esteem specialists by concentrating on the enlistment, choice, preparing and advancement of HR [18]. Besides, it has been contended that in view of the maturing populace in the workforce, new techniques are required to enlist and hold exceptionally qualified specialists to fortify associations' information administration limit [6]. Then again, it has been reprimanded that recognizing and choosing the correct individuals for enlistment and holding those that have been prepared are regions of apprehension for HRD refine [39]. Following this lead, littler firms with couple of representatives who are working generally on gear and new advancements might be emphatically influenced. This is on account of distinguishing and choosing the correct representatives to be enlisted, prepared and created is essential, and is especially basic in littler firms [18], as it specifically identifies with execution [24]. Subsequently, given these issues in HRD hone, managers may need to inspect their employing and limited time criteria to guarantee that the correct $\mathrm{HR}$ are chosen for the fitting occupation [21].

\section{Conclusions}

Each era encounters occasions that shape their points of view. The occasions experienced by Generation Y impacts how they see numerous parts of life [14]. A standout amongst the most imperative normal for the Generation $\mathrm{Y}$ individuals is by all accounts that they are more "out-of-the-box" thinkers [29]. The gyroscopic management approach adjusts towards the planning and instruction for that new gathering of chiefs and can bolster instructors and mentors. Be that as it may, the lion's share of instructors and mentors are of different eras and adjusting to this new approach has officially turned out to be a major test.

\section{References}

[1] Agarwala, T. (2007). Strategic Human Resource Management, New Delhi: Oxford University Press.

[2] Armstrong, M. (2006). Strategic Human Resource Management, 3rd Edition. London: Kogan Page

[3] Ashton, C., Morton, L. (2005). Managing talent for competitive advantage. Taking a systemic approach to talent management. Strategic HR Review, 4(5), 28-31.

[4] Benson, J. and Zhu, Y. (2002). The emerging external labour market and the impact on enterprise's human resource development in China. Human Resource Development Quarterly, 13 (4), 449466.

[5] Bratnicki, M. (2005). Organizational entrepreneurship: Theoretical background, some empirical tests, and directions for future research. Human Factors and Ergonomics in Manufacturing \& Service Industries, 15(1), 15-33.

[6] Chermack, T.J., Lynham, S.A. and Ruona, W.E.A. (2003). Critical uncertainties confronting human resource development. Advances in Developing Human Resources, 5 (3), 257-271.

[7] CIPD (2009). The war on Talent? Part 1. London: Chartered Institute of Personnel and Development.

[8] Collings, D. G., \& Mellahi, K. (2009). Strategic talent management: A review and research agenda. Human resource management review, 19(4), 304-313.

[9] Crampton, S. M., \& Hodge, J. W. (2006). The supervisor and generational differences. Proceedings of the Academy of Organizational Culture, Communications and Conflict, 11, 19-22.
[10] Cunha, M.P., and Cunha, R.C. (2004). The dialectics of human resource management in Cuba. International Journal of Human Resource Management, 15(7), 1280-1292.

[11] Davenport, T.H. (2005). Thinking for a Living. Boston: Harvard Business School Press.

[12] DELOITTE (2010). Talent Edge 2020: Blueprints for the new normal. Deloitte Development LLC . Retrieved from http:/ www.Deloitte.com/us/talent

[13] Dwyer, R J. (2009). Prepare for the impact of the multigenerational workforce! Transforming Government: People, Process and Policy, 3(2), 101-110.

[14] Erickson, T. (2008). Plugged in: The generation $\mathrm{Y}$ guide to thriving at work. Harvard Business Review Press.

[15] Fenn, D. (2010). Upstarts: how gen y entrepreneurs are rocking the world of business and 8 ways you can profit from their success. United States: McGraw-Hill.

[16] Garavan, T.N., Carbery, R., Rock, A. (2011). Mapping talent development: Definition, scope and architecture. European Journal of Training and Development, 36(1), 5-24.

[17] Garavan, T.N., Heraty, N., and Barnicle, B. (1999). Human resource development literature: Current issues, priorities and dilemmas. Journal of European Industrial Training, 23 (4-5), 169179 .

[18] Gardiner, P, Leat, M. and Sadler-Smith, E. (2001). Learning in organisations: HR implications and considerations. Human Resource Development International, 4 (3), 391-405.

[19] Garrow, V., Hirsh, W, (2008). Talent management: Issues of focus and fit. Public Personnel Management, 37(4), 389-402.

[20] Guo, X. (2013). Living in a Global World: Influence of Consumer Global Orientation on Attitudes Toward Global Brands from Developed versus Emerging Countries. Journal of International Marketing, 21 (1),1-22.

[21] Hansen, C. D. (2003). Cultural myths in stories about human resource development: analysing the cross-cultural transfer of American models to Germany and the Cote d'Ivoire. International Journal of Training and Development, 7 (1), 16-30.

[22] Hatum, A. (2010). Next generation talent management: Talent management to survive turmoil. Palgrave Macmillan.

[23] Heinen, J.S., O'Neill C. (2004). Managing talent to maximize performance. Employment Relations Today, 31(2), 67-82

[24] Jacobs, R.L. and Washington, C. (2003) Employee development and organizational performance: a review of literature and directions for future research. Human Resource Development International, 6 (3), 343-354.

[25] Jenkins, J. (2007). English as a lingua franca: Attitude and identity. Oxford University Press.

[26] Jenkins, J. (2007). Leading the four generations at work. Retrieved May 3, 2017, from http://www.amanet.org/movingahead/editorial.cfm?Ed=452

[27] Kersten, D. (2002). Today's generations face new communication gaps. Retrieved May 3, 2017, from http://www.usatoday.com/money/jobcenter/ workplace/communications/2002

[28] Kogan, L. S. and M. J. Muller (2006). Ethnographic study of collaborative knowledge work. IBM Systems Journal, 45(4),759771 .

[29] Kovary,G., Buahene, A.K. (2011). "Loyalty Unplugged: How to Get, Keep \& Grow All Four Generations", N-Gen, Toronto, Canada.

[30] Lewis, M. (2004). Moneyball. The art of winning unfair game. New York: W.W. Norton and Company Inc.

[31] Martin, C. A. (2005). From high maintenance to high productivity. What managers need to know about Generation Y. Industrial and Commercial Training, 37, 39-44.

[32] Miller, M., Hodge, K., Brandt, A. \& Schneider, E. (2013). The young and the restless: Gen Y'ers in the workplace: are you prepared? FDCC Quarterly, 63(3), 226-250.

[33] Niemiec, S. (2000). Finding common ground for all ages. Security Distributing and Marketing, 30.

[34] Piansoongnern, O., Anurit, P. (2010). Talent management: Quantitative and qualitative studies of $\mathrm{HR}$ practitioners in 
Thailand. The International Journal of Organizational Innovation, 3(1), 280-302

[35] Ployhart, R.E., Weekley, J.A., Baughman, K. (2006). The structure and function of human capital emergence: A multilevel examination of the attraction-selection-attrition model. Academy of Management Journal, 49(4), 661-677.

[36] Schuler, R. S., Jackson, S. E., \& Tarique, I. (2011). Global talent management and global talent challenges: Strategic opportunities for IHRM. Journal of World Business, 46(4), 506-516.

[37] Van Ness, R., Melinsky, K., Buff, C., \& Seifert, C. (2010). Work ethic: do new employees mean new work values?, Journal of Managerial Issues, 22 (1), 10-34.

[38] Venter, H. and Venter, E. (2010). "Globalization and the Psychology of the New World Citizen: How the New Global Citizen Comperes to Maslow's Level of Self-Transcendence", International Journal of Interdiciplinary Social Sciences, 5 (6), 2935.

[39] Yadapadithaya, P. S. and Stewart, J. (2003). Corporate training and development policies and practices: A cross-national study of India and Britain. International Journal of Training and Development. Oxford. 7 (2), 108-123. 